\title{
Revisiting Agroforestry for Building Climate Resilient Communities: A Case of Package-Based Integrated Agroforestry Practices in Nepal
}

\author{
Kishor Aryal ${ }^{a^{*}}$, Prakash Singh Thapa ${ }^{b}$, Dhananjaya Lamichhane ${ }^{c}$ \\ ${ }^{a}$ Ministry of Industry, Tourism, Forests and Environment, Sudoorpaschim Province, Dhangadhi, Nepal \\ ${ }^{b}$ Department of Forests and Soil Conservation, Kathmandu, Nepal \\ ${ }^{c}$ Ministry of Industry, Tourism, Forests and Environment, Province no 1, Biratnagar, Nepal
}

\begin{abstract}
Agriculture based livelihoods in developing countries are bearing significant negative impacts due to climate change. In this scenario, agroforestry is one of the best alternatives to cope with climate change and disaster risks. However, the agroforestry approaches adopted in the past were sectoral and partial, and were insufficient to contribute to socio-economic wellbeing and resilient communities. Nepal has been implementing package-based integrated agroforestry since 2016. It is a project approach to advance agroforestry practices by including disaster mitigation, land and water management, and community development activities. This paper reflects on the process and outcomes of the agroforestry practices, implemented by the government in seven super zones of Nepal. The programs have shown fairly satisfactory output in building adaptive capacity to climate change, awareness and active participation in agroforestry development activities. This paper reveals that agroforestry alone cannot be sustained, and hence, it has to be integrated with land productivity enhancement, natural resource management, climate change adaptation, and livelihood support in addition to tree planting in agricultural lands. This paper is crucial in understanding the scope of the package-based integrated agroforestry approach to build climate resilient communities.
\end{abstract}

Keywords:

Resilient Communities;

Agroforestry Systems;

Climate Change Adaptation;

Super Zone Development Program;

Water and Land Management.

Article History:

Received: 17 June 2019

Accepted: 12 September 2019

\section{1- Introduction}

The earth system is under serious threat due to adverse climatic scenarios. Poor communities in developing countries are hardest hit by the impacts of climate change [1]. Accordingly, Nepal has been experiencing climate change effects, leading to increasing temperatures and erratic as well as unpredictable rainfall patterns [2]. In the face of climate change, the primary goal of communities is to increase resilience to climate change on various natural systems as well as the well-being of the communities [3]. Livelihood of more than two thirds of the Nepalese population depend on agriculturebased livelihood activities [4]. Vulnerable communities use their indigenous knowledge to cope with and build resilience to climate change [2].

Agroforestry is an indigenous farming system to increase production and productivity of land resources. As an integration of forestry components with crops and/or livestock, agroforestry can contribute to mitigation as well as adaptation to climate change [5]. Traditional agroforestry practices are believed to be unique in the mountainous region of Nepal, allowing promising solutions for land restoration and slope cultivation [6, 7]. At the same time, agroforestry has the potential for sustainable land management to contribute to rural livelihoods and environmental benefits [7]. Since Nepal is one of the most vulnerable countries to climate change, community based indigenous agroforestry practices, aided with modern technology, are believed to make a significant contribution to building the resilience of the vulnerable communities [8].

\footnotetext{
* CONTACT: Syangjali999@gmail.com

DOI: http://dx.doi.org/10.28991/esj-2019-01193
}

(C) 2019 by the authors. Licensee ESJ, Italy. This is an open access article under the terms and conditions of the Creative Commons Attribution (CC-BY) license (https://creativecommons.org/licenses/by/4.0/). 
Agroforestry practice is in-built into most of the traditional farming systems in Nepal as it enhances food production and the economic wellbeing of farmers in a sustainable manner [9]. However, because of the lack of strategic policy guidance and specific programs, land degradation, deforestation, shifting cultivation, and slope land farming are persistent throughout the country [10]. Moreover, agroforestry practices are being limited to a few sites, and yet the program-based approach to agroforestry has not been properly implemented. In the changing climatic context, agroforestry is valued for its diversified livelihood opportunities for rural communities. Realizing the importance of agroforestry practices, policy makers and conservation practitioners are now considering agroforestry for building climate resilient communities.

\section{2- Agroforestry Systems and Its Components}

Agroforestry is considered as old as agriculture and has not been strictly defined. With much discussion in the recent decades, agroforestry refers to ecological interaction, in time and space, among woody and non-woody components, including plants and/or animals [11]. Two principle components of agroforestry are trees/shrubs and agriculture (including pasture) crops, and they should be artificially managed [12]. Agroforestry is supposed to support and sustain multiple socio-economic and environmental benefits through the integration of trees in agricultural landscapes [13].

Agroforestry system encompasses a triangular interrelationship between woody perennials, agricultural crops and pasture land. Agroforestry performs both protective and productive functions to maintain the ecological balance as well as economic benefits to communities. Agroforestry system can be categorized based on the selection of principle components of the system. Agroforestry system in Nepal is classified in two categories [14], farm-based and forestrybased agroforestry. Farm-based agroforestry includes home gardens, trees in agricultural fields, alley cropping, commercial crops under tree shade, intercropping with horticulture trees, cultivation of annual crops with bamboo, trees around agricultural fields, woodlots, and silvo-fishery. Likewise, forestry-based agroforestry includes Taungya system, shifting cultivation, production of non-wood forest products, silvo-pastoral practices in forests, and specific agriculture practices associated with forests. Likewise, agroforestry systems have also been classified, in other way, in major five groups [15]: multi-strata systems, tree intercropping, silvo-pasture, protective systems and agroforestry woodlots.

\section{3- Agroforestry Policy and Practices in Nepal}

Development of agroforestry is not a new practice in Nepal however, systematic agroforestry practice has been developed recently [16]. Agriculture practice in Nepal is believed to be supported by forestry sector at varying extents [17]. Traditionally, various agroforestry systems were practiced according to different physiographic zones, depending mainly in altitude and aspect. On-farm tree plantation, tree inter-cropping, plantation of fodder trees, and integrated farming system including tree-crop-pastureland has been the major traditional as well as indigenous practices.

Later on, new agroforestry practices have been introduced on a project basis. Various conservation and development organizations were involved in development of agroforestry systems in various part of Nepal. For instance, Terai Community Forestry Development Project introduced Dalbergia sissoo and Cassia Siamea in Terai area [14]. Similarly, various other organizations were focused on introduction of fodder trees and bamboo plantation, contour farming, and hedge row intercropping.

Adequate seedling production and distribution, enabling environment and extension services has been the major approaches adopted for agroforestry development. Various government and non-government institutions along with academic sectors were involved in research and development as well as outreach of appropriate agroforestry practices. For example, Lumle and Pakhribas Agricultural Centers were focused on developing integrated on-farm conservation and extension of the practices [14]. Providing micro-credit facilities to farmers for improvement and adoption of new agricultural practices were the enabling factors however, clearly defined schemes for agroforestry development have been lacking in the past [16].

Along with the field level practices, various policy initiatives were also taken for agroforestry development. Forest Act 1993 recognized the importance of agroforestry system, especially in leasehold forests, as an approach for poverty reduction and protection of degraded forest and shrub lands. Later on, Leasehold Forest Policy 2002 acknowledges the provision of leasing forest land for agroforestry development. Similarly, Revised Forest Policy 2000 highlighted agroforestry in the form of fruit tree intercropping as well as promotion of medicinal and aromatic plants in farming system. Climate Change Policy 2011 mentioned the role of agroforestry in adapting and mitigating the impacts of climate change in rural communities. The National Biodiversity Strategy and Action Plan 2014 has envisioned agroforestry promotion in public lands as a means to conserve biodiversity as well. Action plan of Agriculture Development Strategy 2014 has included the provision for investment in agroforestry development. Forest Policy 2015 highlighted the need of research and development of various agroforestry systems and its extension to farmers.

The government realized that the agroforestry practices is an approach to address the conflicting needs of forest conservation and land productivity enhancement, through time and space. However, project approach in agroforestry 
development put various questions on its sustainability and adoption. Accordingly, government institutions and various development organizations have now been focusing on development of program approach for sustainable agroforestry development throughout the nation. Moreover, The Kathmandu Declaration on Agroforestry (2015) has stressed on research and development as well as the need of national agroforestry policy to mainstream the agroforestry practices in national conservation and development programs.

\section{4- Package-based Integrated Agroforestry through Super Zone Development Program}

Realizing the need of modernization and commercialization in agricultural sector for sustainable development, Government of Nepal has initiated Prime Minister Agriculture Modernization Project (PMA-MP) since 2016. PMA-MP is a high priority project of Nepal aiming to achieve economic growth of Nepal by modernization in agriculture through integrated management of various components of agricultural sector [4]. This project is supposed to bring transformational change in agricultural sector, enhancing the subsistence-based agriculture to commercial farming, to make it a prestigious and profitable profession in the future. The project has four components, characterizing based on the scale of intervention, objectives, and areas of scope. For instance, Pocket Development Program focuses on small scale commercial agriculture production center; Block Development Program focuses on commercial agriculture production center; Zone Development Program focuses on commercial agriculture production and processing center; and Super Zone Development Program (SDP) focuses on highly commercial agriculture production and industrial center [4].

SDPs are being implemented in areas having at least 1000 hectares for highly commercial agricultural production as well as potential agriculture based industrial centers. Major objectives of SDP are to increase agricultural production and productivity, mechanization in agricultural practices, infrastructure development for processing agricultural products, agroforestry development, and research and development for commercialization in agricultural sector. In the initial phase, seven super zones are identified, and various programs are implemented accordingly. By the end of the project in 2027, at least 21 super zones are expected to be identified and established for implementing SDPs [4].

\section{4-1-Super Zones of Nepal}

Super zones were identified to represent different ecological zones of Nepal, ranging from very low-land to high hills (Figure 1). Moreover, the areas also represent locations from Eastern to Far-Western region of Nepal. Moreover, these super zones also represent each of the seven provinces of Nepal. The super zones are targeted to focus on the most suitable crop, vegetables, fruits, and fish farming (Table 1).

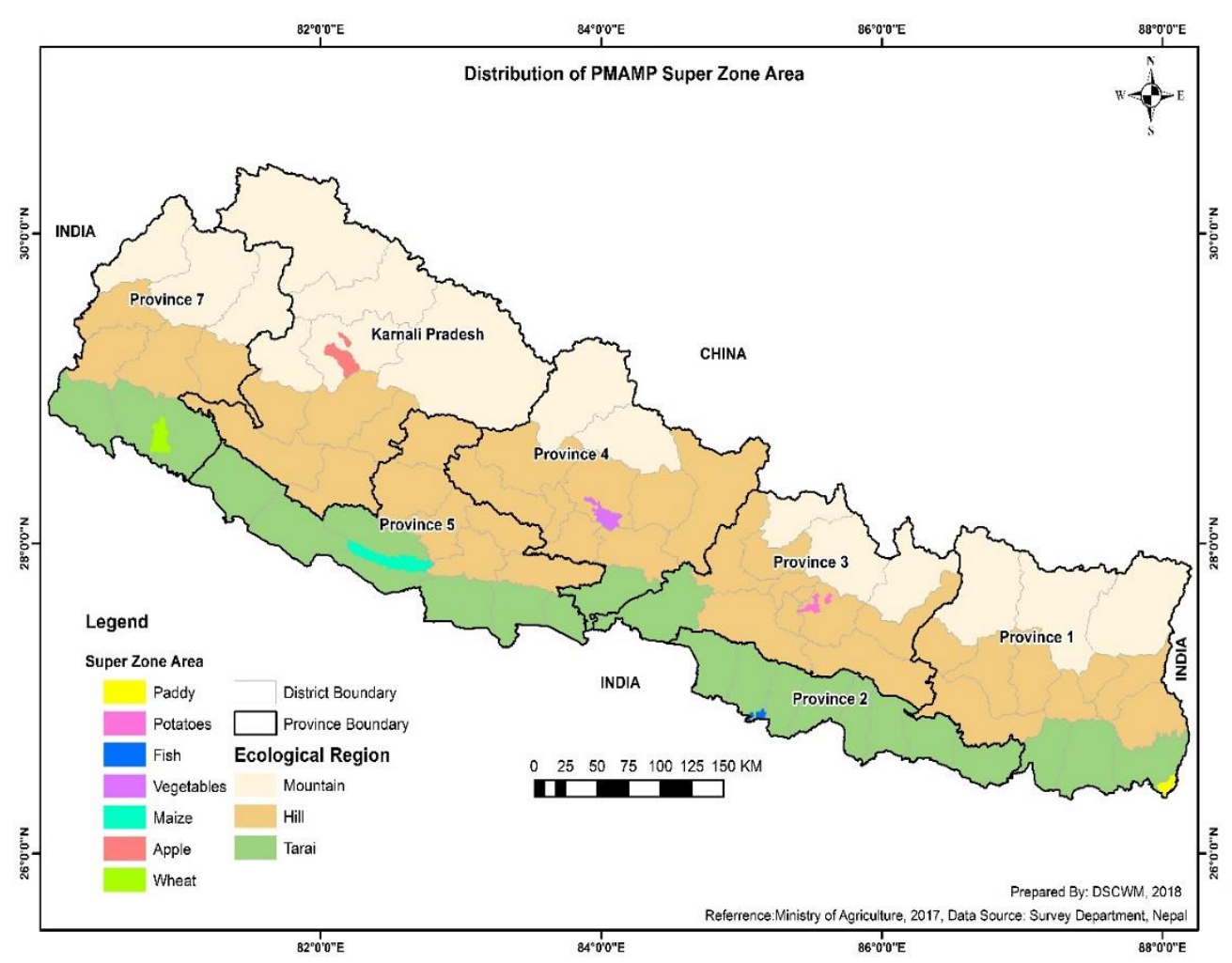

Figure 1. SDP areas of Nepal. 
The super zone selection is a rigorous process. The potentiality of production of the target crops, fruits and fisheries are main basis for the selection of the area. However, various infrastructure facilities are required to be considered as the super zones, such as access to road, irrigation, and electricity. Furthermore, there is essentiality of the availability of financial institutions and access to markets nearby. After the selection of super zone, super zone management committee has to be formed, at local level, to carry out various project activities. Now, the field offices are established in each super zone for implementing and monitoring the program activities.

Table 1. Super zones, its target production and area coverage.

\begin{tabular}{cccccc}
\hline S.N. & Province & District & Target production & Ecological Region & Area $\left(\mathbf{k m}^{2}\right)$ \\
\hline 1 & 1 & Jhapa & Paddy & Terai & 102.24 \\
2 & 3 & Kavrepalanchok & Potato & Hill & 90.19 \\
3 & 2 & Bara & Fish & Terai & 51.26 \\
4 & Gandaki & Kaski & Vegetables & Hill & 217.12 \\
5 & 5 & Dang & Maize & Terai & 466.17 \\
6 & Karnali & Jumla & Apple & High hill & 285.23 \\
7 & Sudoorpaschim & Kailali & Wheat & Terai & 222.33 \\
\hline
\end{tabular}

\section{4-2-Agroforestry Program in the Super Zones}

SDPs are mainly focusing on agricultural production in the selected areas. The ongoing activities include program orientation, technical support to farmers and communities, institutional support, infrastructure development, and facilitation in commercialization of the target agro-based product. It includes activities from establishing high-tech nursery for seedling production to the establishment and development of agro-based industries for value addition of the products as well as accessible market.

Package-based agroforestry development is one of the priority components of the project in super zones. Ministry of Forests and Environment is mandated for effective implementation of agroforestry programs of the project. Accordingly, Department of Forests and Soil Conservation (DFSC) under the ministry has implemented the programs in the selected super zones since 2017.

Regarding the agroforestry components, government of Nepal has been implementing activities for conservation of soil and water, protecting soil from degradation, and maintaining land productivity of the area. Traditionally, agroforestry development activities were focused on seedling production and distribution for plantation in agricultural areas. It was focused mainly on the interaction of forest, livestock and agriculture. These activities used to be supplemented by creating awareness and developing model farmers and communities. Those traditional practices were unable to address the integration of various soil, water and landform characteristics. Because of the sectoral approach, agroforestry programs could not gain adequate attention of the communities and policy makers.

Learning from the past experiences, agroforestry development under PMA-MP has been designed to comprehend various aspects of agroforestry components, including crop/tree production, land (soil) management, and water source protection, all through participatory approach. Adequate quality seedling production, its distribution and plantation in farm land as well as pasture land has been the core focus of the program. However, formation of in-situ institutions, such as community development groups and their capacity building, has been a key step in participatory planning and organization of agroforestry development activities through integrated management plan. Various support activities have also been conducted in the super zones to institutionalize farm-forestry activities. Support activities that are identified and implemented in the super zones are land productivity conservation, land reclamation, water source protection, conservation pond construction, irrigation canal protection, and river/stream bank protection. The effectiveness of such practices are evaluated on the basis of benefitted household, employment generation, conserved land area and water sources, as well as the gross land productivity.

Satisfactory achievement has been made by implementing agroforestry components of PMA-MP in the seven super zones of Nepal by DFSC. The annual progress of the Fiscal Year 2016/17 program is presented in Table 2 [18]. 
Table 2. Annual progress of seven SDPs under PMA-MP [18].

\begin{tabular}{|c|c|c|c|c|c|c|c|c|c|c|}
\hline \multirow{2}{*}{ S.N. } & \multirow{2}{*}{ Description } & \multirow{2}{*}{ Unit } & \multicolumn{7}{|c|}{ Super-zone Districts } & \multirow[t]{2}{*}{ Total } \\
\hline & & & Kailali & Jumla & Kavre & Jhapa & Dang & Bara & Kaski & \\
\hline 1 & Land productivity Conservation & Hectare & 12 & 6.5 & 150 & 15 & 85 & 4 & 6.5 & 279 \\
\hline 2 & Community Development Group formation & No. & 4 & 2 & 5 & 5 & 7 & 3 & 4 & 30 \\
\hline 3 & Land management and water source protection & places & 9 & 7 & & & 1 & 2 & 3 & 22 \\
\hline 4 & Seedling production /Distribution/Plantation & No. & 12000 & 90000 & 5000 & 60000 & 5400 & 2500 & 52000 & 226900 \\
\hline 5 & Management Plan Development & No. & 1 & 1 & 1 & 1 & 1 & 1 & 1 & 7 \\
\hline 6 & Capacity Building (Training) & No. & 2 & 3 & 2 & 2 & 4 & 2 & 4 & 19 \\
\hline 7 & River /stream Bank Protection & $\mathrm{Km}$ & & & 0.5 & 1 & 3 & & & 4.5 \\
\hline 8 & Benefitted household & No. & 130 & 601 & 230 & 723 & 565 & 170 & 388 & 2807 \\
\hline 9 & Employment generation & $\begin{array}{l}\text { Man } \\
\text { days }\end{array}$ & 1507 & 4604 & 1260 & 2500 & 233 & 120 & 1342 & 11566 \\
\hline
\end{tabular}

The progress of the package-based agroforestry development programs in the super zones indicate that the agroforestry development should not focus only on seedling production and plantation of tree species in crop lands. Instead, integrated management of land and water resources enables the good practices along with community mobilization and capacity building. Although, it is too early to conclude findings through a single year intervention, integrated approach and concentrated activities is likely to improve water availability and land management practice. For instance, in the lowland areas, conservation measures have been effective in land reclamation, river bank control and water recharge. Consequently, it seems promising to upscale and out-scale agroforestry practices to diversify the livelihood opportunities. Ultimately, it helps in capacity building of the communities for adaptive management in the changing climatic and disaster risk scenario.

\section{5- Scope of SDP in Building Climate Resilient Communities}

Impact of climate change is wide spread, and it has negative impacts in various aspects of rural livelihood [19]. Those impacts can be observed through increased and uncertain impacts on hydrological functioning, depletion of water sources, decrease in soil productivity, ecological degradation, increased disaster risk, resulting in reduction of land productivity and economic performances [20-23]. Agriculture based communities in the rural areas are supposed to be hardest hit by the climate change impacts. In the face of climate change, major considerable aspects are both ecological resilience and adaptation capacity of communities [24]. Capacity building of communities in terms of bearing the stress and shocks due to climate change impacts, and nature-based solutions in sustaining ecological resilience are major factors to consider.

Agroforestry practice in SDP is an integrated approach that considers not only the core components of agroforestry but also bio-physical and socio-economic aspects of the concerned communities (Figure 2). This agroforestry approach focuses on land protection, degraded land rehabilitation, soil erosion control and overall land productivity management. Moreover, conservation and protection of water source, management of water recharge zones, restoration of catchment area and multiple use of water for various purposes also considered as the support program for agroforestry. Land and water management activities contribute to increase production and productivity of the area, which ultimately contribute to food security and well-being of local people.

Social and economic dimension plays crucial role in developing and institutionalizing best agroforestry practices. Community mobilization through user group formation and implementation of agroforestry program through the community groups has shown satisfactory results. Accordingly, social and gender inclusion, social mobilization and capacity building of the communities through various training and extension programs form a basis for sustainable development of agroforestry practices. The agroforestry programs support in organizing community development groups for self-mobilization in agroforestry activities [16]. Training activities along with the practical application of the knowledge in the super zones is effective in deep understanding the social and ecological functioning of agroforestry practices by the communities themselves. 


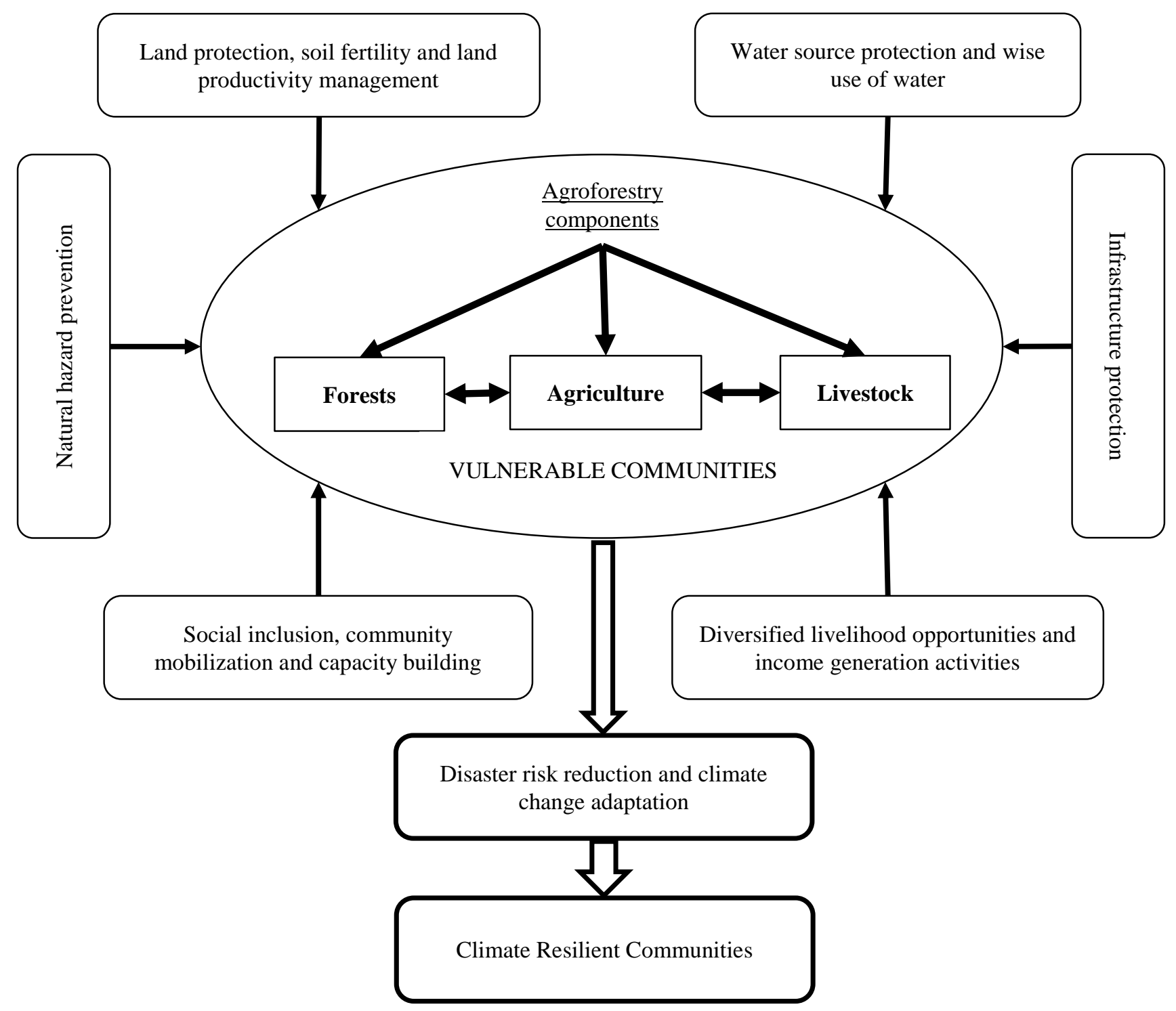

Figure 2. Package-based agroforestry in SDP.

Considering the specific needs of the communities, various income generating activities and other economic opportunities should be provided to mainstream the agroforestry system in the community practice of living and sustaining. On the production side, agroforestry program supports establishment and management of multipurpose tree plantation for diversified production such as fuel-wood, fodder, timber as well as food products. Such integration offers solution to various land use and land management issues, including food security, environment conservation and climate change adaptation [15]. Diversified agricultural and forest products also creates opportunities for the marketing and income generation of the rural farm-based communities [14]. Along with the social empowerment as well as land and water management, potential natural hazard prevention and important infrastructure protection measures should be carefully designed and developed with priority.

Participatory planning and formulation of management plan for implementation of agroforestry programs is a cornerstone for sustainable agroforestry development. Integrated land and water management program helps in improving the overall land productivity of area. Agroforestry practices can show significant impact on food security, mitigation and adaptation to climate change and provisioning of ecosystem services [15]. Increased land production and productivity outlays various options for diversified livelihood options as well as the ecological resiliency [16]. Improvement in soil fertility, aboveground and underground biomass storage, nutrient regulations, diversified production and water regulation helps in building climate resilient communities in the long-term basis [15]. The package-based approach to agroforestry, as in SDPs, is expected to contribute to reduce the disaster risk at one hand, and on the other hand it helps communities to better adapt to climate change. This enhanced capacity and minimized risk would lead to climate resilient communities in Nepal. 


\section{6- Discussion and Analysis of Agroforestry Practices}

Nepal poses one of the most vulnerable agricultural based economies in the world. Moreover, rural population in Nepal who depends on subsistence farming for livelihood are facing significant loss in agricultural productivity due to climate induced stress [25]. It affects hydrological regime and water balance leading to adverse effect on water availability and water source disappearance [26]. Climate change along with disaster risk uncertainty, play crucial role in exacerbating climate extreme events and socio-economic challenges [27]. These uncertain and multiplier impacts of climate change is severe in agricultural domain. In connection to this, agroforestry is standing as an alternative approach to farming practices alone to cope with uncertainties of the impacts of climate change and triggering disaster risks.

Agroforestry system is contributing to livelihood support along with the ecological benefits. Social and economic benefits from various agroforestry practices are directly and indirectly contributing to the resilience of poor and vulnerable communities. In the changing climatic scenario and uncertain ecosystem functioning, agroforestry system helps in diversifying livelihood practices on one hand. On the other hand, this system helps in reducing pressure on forest ecosystem as well as in supporting and regulating ecosystem services.

Agroforestry is a reliable option for rural farmers in Nepal. However, it has rarely been recognized in the past national policies and periodic plans of Nepal. Various research and development activities were conducted on a project basis in the past, though with the termination of project the agroforestry practices could not be sustained. None of the past approaches could put adequate mechanisms to include and mainstream the agroforestry practices in resource management and development policies.

In the recent years, agroforestry has gained significant attention at the policy level. For instance, periodic plan of the country, agriculture development strategy, forest policy, forest sector strategy and sustainable development goals have included agroforestry as a promising option for enhancing land productivity and food security. However, these policy instruments have not explicitly mentioned about the clear approaches, development mechanisms and targets for the agroforestry development. In the policy level, few discourses on agroforestry practices have been recognized to sensitize local communities and development partners. Though, focused rules and regulations, coordinated institutional approach, actors' constellation and organizational set up, and adequate resource allocation has been lacking at varying extent.

Farm-based and forestry-based agroforestry programs have been widely implemented. Establishment and management of home gardens, sparse tree plantation in agricultural fields, horticulture intercropping and silvo-pastoral practices are common agroforestry systems adopted by Nepalese farmers. Yet, the agroforestry program has been implemented through a sectoral approach with just incorporation of trees, crops and livestock in farming practices. A holistic approach to agroforestry development has been lacking. Agroforestry programs should not be limited on production of seedlings and plantation, but it should incorporate other various aspects such as soil fertility management, land productivity enhancement, water conservation and wise use, livelihood support and diversified production of food and forestry products in a sustainable basis [7]. Past practices were inadequate to cater the multiple components of water and land management. Accordingly, even after the recognition of few good examples of agroforestry practices in a small scale, such practices could not be extended and applied to a wider agricultural and forestry domain.

Piloting and demonstration of good agroforestry practices have been done in the past, such as sloping agricultural land technology, horticulture intercropping, the Taungya system, and the production of non-wood forest products [14]. Education and extension as well as technical support for agroforestry have also been practiced. However, documentation of best practices and scaling up of the practices for wider application has been lacking. Although the potential of agroforestry for land productivity, economic returns, and environmental services has been stated elsewhere, practical application of the agroforestry principles and its meaningful achievement has yet to be demonstrated. Lack of research and development on site-specific geo-morphological characteristics, climatic conditions, and agro-ecological ecosystems is one of the major challenges in documenting good practices. Furthermore, inadequate focus on extension and capacity building of farmers and communities is hindering sustainable agroforestry development.

Role of agroforestry has been recognized at a narrow level as a complementary approach in farming systems. Agroforestry practice has mostly been used for the production of fodder and fuel wood, along with agricultural production. National policy and programs were also insufficient to realize the multiple benefits and role of agroforestry in ecological resilience and capacity building of communities. Recently, agroforestry programs and practices are being realized to contribute to multiple aspects of rural livelihood, capacity building of the communities, food production, forestry services, and land productivity. In the context of climate change impacts on rural livelihoods, package-based agroforestry practices can contribute to climate change adaptation.

\section{7- Conclusion}

The impact of climate change is more pronounced in the livelihoods of agriculture based communities. The establishment of good agroforestry practices and their sustainable development in farm-based communities has been recognized as a potential solution to diversify rural livelihood options and to maintain ecological balance. Past policies 
and practices of agroforestry development were sectoral and had a very limited scope in terms of rural livelihoods. Learning from past experiences, the government of Nepal has initiated a package-based agroforestry program through a super zone development program to concentrate the farm-based development activities and integrate various aspects of land and water management. Immediate results from the program indicate that the package-based agroforestry program is fairly successful in capacity building of the communities. Sensitization of the communities and meaningful participation in the establishment and development of agroforestry practices are important achievements of the program. Moreover, support of tree crop plantation, along with soil and water conservation and land management activities, offers this system as a clear indication of promising approach in diversifying local livelihood options. Sustainable land management and ecosystem resilience are closely linked with integrated agroforestry practices, which provide ample opportunities to communities by harnessing the multiple benefits of agroforestry. Reduced risk of disaster and increased community capacity ensure climate resilient communities. Clear policy guidance for agroforestry development, support with land and water management strategies, and up-scaling of the good practice might be the cornerstone in building better communities in the face of climate change through enhancing capacity of communities and resilient ecosystems.

\section{8- Conflict of Interest}

The author declares that there is no conflict of interests regarding the publication of this manuscript. In addition, the ethical issues, including plagiarism, informed consent, misconduct, data fabrication and/or falsification, double publication and/or submission, and redundancies have been completely observed by the authors.

\section{9- References}

[1] Atta-ur-Rahman, Gulsan Ara Parvin, Rajib Shaw, and Akhilesh Surjan. "Cities, Vulnerability, and Climate Change." Urban Disasters and Resilience in Asia (2016): 35-47. doi:10.1016/b978-0-12-802169-9.00003-3.

[2] MoSTE, "Indigenous and Local Knowledge and Practices for Climate Resilience in Nepal, Mainstreaming Climate Change Risk Management in Development." Government of Nepal/ Ministry of Science, Technology and Environment (MoSTE), Kathmandu, Nepal, 2015.

[3] Santiago, Miguel Pardellas, Lucía Iglesias da Cunha, and Pablo Á. Meira Cartea. "Resilient Communities to Climate Change. Environmental Education and Movement in Transition Connection." Procedia - Social and Behavioral Sciences 237 (February 2017): 925-930. doi:10.1016/j.sbspro.2017.02.130.

[4] MOAD, "Project Document of Prime Minister Agriculture Modernization Project." Government of Nepal/ Ministry of Agriculture Development (MOAD), Kathmandu, Nepal, 2017.

[5] Hernández-Morcillo, Mónica, Paul Burgess, Jaconette Mirck, Anastasia Pantera, and Tobias Plieninger. "Scanning AgroforestryBased Solutions for Climate Change Mitigation and Adaptation in Europe.” Environmental Science \& Policy 80 (February 2018): 44-52. doi:10.1016/j.envsci.2017.11.013.

[6] Rana, Santosh Kumar, Hum Kala Rana, Krishna Kumar Shrestha, Suresh Sujakhu, and Sailesh Ranjitkar. "Determining Bioclimatic Space of Himalayan Alder for Agroforestry Systems in Nepal.” Plant Diversity 40, no. 1 (February 2018): 1-18. doi:10.1016/j.pld.2017.11.002.

[7] Schwab, Niels, Udo Schickhoff, and Elke Fischer. "Transition to Agroforestry Significantly Improves Soil Quality: A Case Study in the Central Mid-Hills of Nepal." Agriculture, Ecosystems \& Environment 205 (July 2015): 57-69. doi:10.1016/j.agee.2015.03.004.

[8] Ifejika Speranza, Chinwe, Friday U. Ochege, Thaddeus C. Nzeadibe, and Agwu E. Agwu. "Agricultural Resilience to Climate Change in Anambra State, Southeastern Nigeria." Beyond Agricultural Impacts (2018): 241-274. doi:10.1016/b978-0-12812624-0.00012-0.

[9] Neupane, Ramji P, and Gopal B. Thapa. "Impact of Agroforestry Intervention on Soil Fertility and Farm Income Under the Subsistence Farming System of the Middle Hills, Nepal.” Agriculture, Ecosystems \& Environment 84, no. 2 (April 2001): 157167. doi:10.1016/s0167-8809(00)00203-6.

[10] Acharya, Anil Kumar, and Narayan Kafle. "Land Degradation Issues in Nepal and Its Management Through Agroforestry." Journal of Agriculture and Environment 10 (August 12, 2009): 133-143. doi:10.3126/aej.v10i0.2138.

[11] Nair P. V. R. and, Garrity D. P. N., “Agroforestry research and development: the way forward,” Nair PKR Garrity 2012 Agrofor. - Future Glob. Land Use Dordr. Spinger, 2012.

[12] Mosquera-Losada, M. R., J. H. McAdam, R. Romero-Franco, J. J. Santiago-Freijanes, and A. Rigueiro-Rodróguez. "Definitions and Components of Agroforestry Practices in Europe.” Agroforestry in Europe (n.d.): 3-19. doi:10.1007/978-1-4020-8272-6_1.

[13] World Agroforestry Centre, “Transforming Lives and Landscapes. Strategy 2008-2015.” World Agroforestry Centre, Nairobi, Kenya, 2008. 
[14] Amatya, S. M. “Opportunities for Agroforestry in Nepal,” Nepal J. Sci. Technol., vol. 1, no. 1, 1999. Retrieved from http://www.nast.org.np/njst/index.php/njst/article/view/13

[15] Nair, P. K. R. “Climate Change Mitigation: A Low-Hanging Fruit of Agroforestry.” Advances in Agroforestry (2012): $31-67$. doi:10.1007/978-94-007-4676-3_7.

[16] Amatya, S. M., Cedamon, E., and Nuberg, I. Agroforestry Systems and Practices in Nepal-Revised Edition. Rampur, Nepal: Agriculture and Forestry University, 2018.

[17] Tuladhar, A. R. "Agroforestry in Nepal," presented at the Expert Consultation on Agroforestry in the Asia-Pacific Region, Bangkok (Thailand), 15-18 May 1990, 1990. Retrieved from http://agris.fao.org/agris-search/search.do?recordID=XF9096531.

[18] DSCWM, “Annual Progress Report,” Department of Soil Conservation and Watershed Management (DSCWM), Kathmandu, Nepal, 2018.

[19] Pandey, Rajiv, Praveen Kumar, Kelli M. Archie, Ajay K. Gupta, P.K. Joshi, Donatella Valente, and Irene Petrosillo. "Climate Change Adaptation in the Western-Himalayas: Household Level Perspectives on Impacts and Barriers." Ecological Indicators 84 (January 2018): 27-37. doi:10.1016/j.ecolind.2017.08.021.

[20] Karimi, Vahid, Ezatollah Karami, and Marzieh Keshavarz. "Climate Change and Agriculture: Impacts and Adaptive Responses in Iran.” Journal of Integrative Agriculture 17, no. 1 (January 2018): 1-15. doi:10.1016/s2095-3119(17)61794-5.

[21] Pumo, D., E. Arnone, A. Francipane, D. Caracciolo, and L.V. Noto. "Potential Implications of Climate Change and Urbanization on Watershed Hydrology.” Journal of Hydrology 554 (November 2017): 80-99. doi:10.1016/j.jhydrol.2017.09.002.

[22] Yu, Shyi-Liang, Ying-Chien Chu, and Huei-Min Tsai. "Environmental Changes and Building Resilient Community in Penghu Islands.” Journal of Marine and Island Cultures 5, no. 2 (December 2016): 126-132. doi:10.1016/j.imic.2016.09.003.

[23] Zhu, Yongnan, Zhaohui Lin, Jianhua Wang, Yong Zhao, and Fan He. "Impacts of Climate Changes on Water Resources in Yellow River Basin, China.” Procedia Engineering 154 (2016): 687-695. doi:10.1016/j.proeng.2016.07.570.

[24] Lohmann, Hilary. "Comparing Vulnerability and Adaptive Capacity to Climate Change in Individuals of Coastal Dominican Republic.” Ocean \& Coastal Management 132 (November 2016): 111-119. doi:10.1016/j.ocecoaman.2016.08.009.

[25] Chalise, Sudarshan, Athula Naranpanawa, Jayatilleke S. Bandara, and Tapan Sarker. "A General Equilibrium Assessment of Climate Change-induced Loss of Agricultural Productivity in Nepal.” Economic Modelling 62 (April 2017): 43-50. doi:10.1016/j.econmod.2017.01.014.

[26] Bajracharya, Ajay Ratna, Sagar Ratna Bajracharya, Arun Bhakta Shrestha, and Sudan Bikash Maharjan. "Climate Change Impact Assessment on the Hydrological Regime of the Kaligandaki Basin, Nepal." Science of The Total Environment 625 (June 2018): 837-848. doi:10.1016/j.scitotenv.2017.12.332.

[27] Van der Keur, Peter, Caroline van Bers, Hans Jørgen Henriksen, Hari Krishna Nibanupudi, Shobha Yadav, Rina Wijaya, Andreas Subiyono, et al. "Identification and Analysis of Uncertainty in Disaster Risk Reduction and Climate Change Adaptation in South and Southeast Asia.” International Journal of Disaster Risk Reduction 16 (June 2016): 208-214. doi:10.1016/j.ijdrr.2016.03.002. 